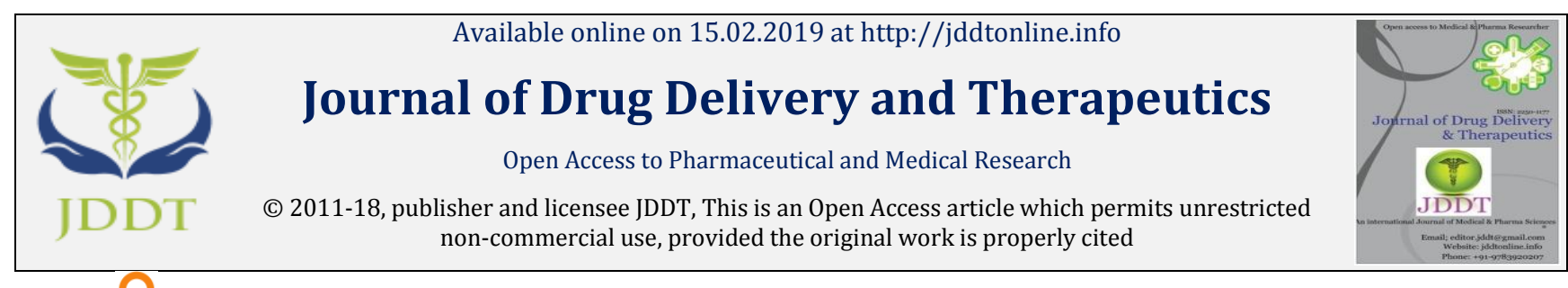

Open $\odot$ Access

Review Article

\title{
An appraisal of Unani fundamentals in the management of Humma (fever)
}

\author{
Akhtar Md. Wasi ${ }^{1^{*}}$ and Naseer Mursaleen ${ }^{2}$ \\ ${ }^{1}$ Assistant Professor, Department of Moalajat, School of Unani Medical Education and Research, Jamia Hamdard, New Delhi, India \\ ${ }^{2}$ Assistant Professor, Department of Moalejat, A.K. Tibbiya College, AMU, Aligarh, India
}

\begin{abstract}
The fever has been described in Unani System of Medicine in a very elaborative manner. Besides controlling raised body temperature, the management also comprises other measures to achieve holistic treatment. The basic modes of treatment viz. Ilaj bil Ghiza (dietotherapy), Ilaj bil Tadbeer (regimenal therapy) and Ilaj bil Dawa (pharmacotherapy) are taken into account as per the basic principles of treatment in Unani medicine. Use of cold water and other drinks (mashroob) reduces body temperature, while use of easily digestible and jayyadul kemoos diet like maul asl, ma'ul shaeer, kashak-us-shaeer, aash-e-jau etc. are given in small amounts, just to provide strength to tabiát and to avoid further increase in morbid matter. Various types of drug used to manage different kinds of fever are Dafe Humma, Muarriqat, Musaffiyat wa Muaddilat, Mubarridat wa Musakkinat, Mudirrat, Muqawwi Kabid and Mufarrehat.
\end{abstract}

Keywords: Humma, Fever, Unani, Management, Basic Principles

Article Info: Received 07 Jan 2019; Review Completed 09 Feb 2019; Accepted 10 Feb 2019; Available online 15 Feb 2019

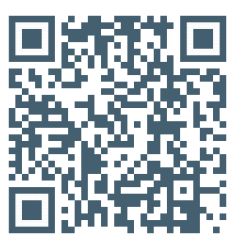

Cite this article as:

Akhtar MW, Naseer M,An appraisal of Unani fundamentals in the management of Humma (fever), Journal of Drug Delivery and Therapeutics. 2019; 9(1-s):516-519 http://dx.doi.org/10.22270/jddt.v9i1-s.2430

*Address for Correspondence:

Md. Wasi, Akhtar Assistant Professor, Department of Moalajat, School of Unani Medical Education and Research, Jamia Hamdard, New Delhi, India

\section{INTRODUCTION}

The fever has been described in Unani System of Medicine in a very elaborative manner. Different types of fever, their pathophysiology, clinical presentation and management are illustrated very clearly.

Besides controlling raised body temperature, the management comprises other measures also to achieve holistic cure. The management includes basic modes of treatment viz. Ilaj bil Ghiza (dietotherapy), Ilaj bil Tadbeer (regimenal therapy) and Ilaj bil Dawa (pharmacotherapy) step by step according to the well defined principles laid down in Unani System of Medicine. Therefore, to manage raised body temperature patients are advised to take barid mashroobat (cold beverages), then some procedures of regimenal therapy like cold sponging, ghusl-e-barid (cold bath) etc. is done, and finally some medicines are prescribed as per need.

In this paper, an attempt has been made to categorize the different means of management of fever under the headings of well known methods of treatment of Unani Medicine. Unani physicians have extensively discussed the line of treatment of fever, but in scattered manner. In this paper an effort has been made to explore these guidelines of treatment and their rationality under specific headings, so that a quick review can be made while discussing the basic principles of management of fever.

The details of all modes of treatment and their possible mechanism of action (the way they normalize the body temperature) and how they support the body to combat the ailing condition of fever is described as follows:

\section{ILAJ BIL GHIZA (DIETOTHERAPY)}

Basic concept of Tib-e-Unani (Unani Medicine) is that tabiát (Medicatrix naturae) is the real mualij (physician), hence it becomes necessary to protect and strengthen this tabiát and diet management plays a vital role in it. Therefore, if the subject is strong enough to fast, it is better to do faaqa (fast/ avoid meals), so that the tabiát remains free from the digestive process and may pay full attention for the restoration of health.

The patients of Humma yaum should not be advised faaqa (fast/ avoid meals), as it is supposed that this fever will subside within a day or two, and will not affect the tabiát too much. But the patients of humma yaum ishaliya (fever with loose motions) in which the etiology is tukhma must be advised faaqa ${ }^{1}$.

And if it is not possible to do faaqa (fast), Ghiza-e-lateef wa jayyadul kemoos (light and nutritious diet) is given, so that 
the tabi'at (Medicatrix naturae) remains strong enough to fight with the ailing condition. If fever is acute and it is supposed to continue only for a week and quwa/tabiát is not too weak, then only liquid diets like ma'ul asl, julab, juice of pomegranate and milk etc. may be given to the patient.

When it expected that this fever will continue for 2 weeks then Milk, Barley water, Pearl sago (Sagoodana) should be given. If it is difficult to assess the period of fever, then after a few days of using ma'ul asl the patient should be given ma'ul shaeer, as it is easily digestible, produces good quality blood and moreover the temperament of ma'ul shaeer is barid ratab.

In general all patients of fever should be given liquid diet as it helps in normalizing the body temperature by improving diuresis and diaphoresis like ma'ul asl, sikanjbeen, aab-eanar, aab-e-naranj, aab-e-tarbooz, julab, sharbat-e-gul, ma'ul shaeer, kashak-us-shaeer, Milk, etc. But old patients and children should never be put on fasting as they are too weak to tolerate it $1,2,3$.

Diets advised to the patients must be barid (cold) and ratab (wet) and in temperament as it will antagonize the effect of fever because it is a disease of soo-e-mizaj haar yabis (deranged hot and dry temperament) and use of such diets are very much rational as per the basic principles of management of Unani Medicine i.e. ilaj bil zid (antagonistic therapy) ${ }^{4}$.

Reduction in the quantity of diet is beneficial in all types of fevers as tabiát of the patient confronts with the disease more efficiently and effectively ${ }^{5}$.

According to Ibn-e-Sina 'aash-e-jau' (Barley water) is the best diet for the patients of fever. Ibn-e-Sina has cited 12 qualities of aash jaut:

\section{Thick in consistency}

2. Viscid

3. Easy to swallow

4. Energetic

5. Provides wetness

6. Easy to digest

7. Cold in temperament

8. Quenches the thirst

9. Easily absorbed

10. Does not stick in the alimentary passage

11. Enhance the phlegm

12. Non-flatulent

The patients in which use of aash-e-jau is contraindicated may be given ma-ul asl, but it has less nutritive value and sikanjbeen may be another substitute for ma-ul asl ${ }^{4}$.

While managing the patients of haar mizaj (hot temperament) or safravi mizaj (bilious temperament) usually sour syrups are used and sweet syrups are avoided except sharbat neelofar, which can be used in such patients. If sour syrups are being used it should be well diluted. Sikanjbeen and other sour material are used to prevent the tendency of fever to change into humma safravi (bilious fever $)^{5}$.

Patients of fever should not be given fatty meals, because it may increase the morbid matter except roghan badam ISSN: 2250-1177 sheerin as Unani physicians have advocated its use in the management of fever 5 .

If the diet of the patient of fever is not regulated according to the principles as mentioned, it may lead to the formation of akhlat-e-ghair saleha (bad humours) and may enhance the quantity of morbid material, therefore may increase the course/ severity of the fever.

If food is given to the patient, it should be given during waqfa (afebrile phase) or during lowest temperature so that it can be digested properly. Therefore, the patient should be empty stomach when the body temperature rises so that tabiát (Medicatrix naturae) may concentrate to eliminate the causative factor of fever rather to divert towards the digestive system ${ }^{2,6}$.

Regarding use of cold water in fever following rules are made by the physicians of Unani system of medicine:

- Cold water is neither always beneficial nor always harmful.

- Fever is like fire, therefore water is the best mean to counter it, for high grade fevers cold water is medicine and cure in itself; hence Shaikh Bu Ali Sina says: the patients of humma ufoonia (infective fever) should not be stopped to use cold water and the patients of humma safravi (bilious fever) must be given cold water.

- In high grade fever cold water provides strength to the quwwat-e-tabáia/ tabiát (Medicatrix naturae).

- Cold water often helps quwwat-e-tabáia/ tabiát to remove morbid matter from the body through vomiting, urination, sweating and even through loose stools; therefore it is wise to give cold water to the patients of high grade fevers ${ }^{3,4,7}$.

- Patients get relief form humma muharraqa (high grade fever) when given plenty of cold water until it induces chills/ rigors, this will normalize the temperature or will convert humma muharraqa into humma balghamia (phlegmatic fever) ${ }^{6}$.

But cold water should be used with precaution in patients of fever with following conditions:

- Morbid matter is thick

- Cold \& cough or any respiratory disorder

- Deranged temperament of stomach or liver

- Inflammation in any viscera

- Pain

- Debilitating condition

- Anaemia

Patients of humma safravi (bilious fever) should be given cold water except in those subjects who have weak innate heat, and in those patient also who are not habitual for drinking cold water 6 .

The Sikanjbeen quenches the thirst in fever, cools the hiddat of Safra, and keeps the oral cavity wet and moist. Sirka (vinegar) of the sikanjbeen breaks the heat of Safra moreover it converts Ghaleez (thick) morbid matter into Lateef (thin) making it easy to remove from the body, whereas Honey provides innate heat and nutrition to the ailing body ${ }^{6}$.

In case when cold water is harmful, cold Sikanjbeen is the best substitute ${ }^{3}$. 
If fever is associated with inflammation in liver then only Sikanjbeen should be used to combat the fever6.

If constipation is a concomitant presentation in the patients of fever then no food should be allowed until the constipation is relieved and very first emphasis is given to clear the bowel. Stasis of fuzla (faecal matter) in the máa mustqeem (colon) for a longer period may lead to formation of of qimoos-e-ghair saleha and when this is utilized in the liver, akhlat-e-ghair saleha is produced. Thus it becomes necessary to clear the bowel.

Another concept to manage the constipation first is that; if the bowel is not clear and remains full of fuzla (faecal matter), the tabiát (Medicatrix naturae) cannot give full attention to manage the fever. Moreover constipation leads to flatulence and fullness of abdomen. In a state when the bowel is free from the faecal matter the tabiát (Medicatrix naturae) works more attentively, efficiently and properly to normalize the body functions. Thus it is necessary to clear the bowel first.

For the management of constipation, well defined guidelines are there like:

- Only laxatives should be used and purgatives should be avoided (purgatives weakens the tabiát of the patient).

- Laxatives used should be cold and wet in their temperament like:

- Saboos-e-aspghol (aspgol husk)

- Gulqand maahtabi

- Khameera banafsha

- Tamarhindi (tamarind pulp) in large quantity

- Aalu Bukhara (plum pulp) in large quantity

Use of above mentioned mulayyanat (laxatives) are the best options as they have laxative as well as mubarrid and musakkin properties to lower the body temperature to normal.

In high grade fever aalu bukhara, zulal tamar hindi with shakar or anar tursh with ussara shaljam with shakar may be used to manage constipation 7,8 .

If there is qulanj (severe constipation) with fever, kashak aab should be given to remove the faecoliths along with mild enema ${ }^{6}$. Shaikh Bu Ali Sina advocates using Mild purgative enema (huqna) instead of oral purgative in this condition. Mild enema clears the bowel only by local effect at the lower alimentary canal without disturbing the whole body whereas purgatives affect the whole body as it gets digested and absorbed leading to disturbance of the normal physiological mechanism. The following nuskha may be used for this purpose ${ }^{4}$ :

Aab-e-Tarbooz, Aab-e-Khiyar, Aab-e-Kaddu, Aab-e-Khurfa, Roghan-e-Gul with little Kafoor

\section{ILAJ BIL TADBEER (REGIMENAL THERAPY)}

Ilaj bit Tadbeer includes keeping the patient in a cold and moist ambient. This can be achieved by following ways and all these tadabeer lowers the body temperature of the patient.

- Keep the patient in a water tub

- Spraying cold water mixed with itr-e-khas, arq-e-gulab or arq-e-kewda

\section{- Waving moist hand fans in front of the patient}

One of the important tadabeer to lower down the raised body temperature in fever is to put a cloth over the forehead, abdomen and on the hands and feet of the patient and wetting this cloth in ice cooled sirka and arq-e-gulab.

If these tadabeer fail to bring the body temperature normal, then the patient is being drenched in cold water known as ghusl-e-barid. In case of high grade fever every possible measure should be taken to lower down the temperature in order to avoid any complication.

\section{ILAJ BIL DAWA (PHARMACOTHERAPY)}

The drugs used are dafe humma, muárriqat, musaffiyat wa muáddilat, mubarridat wa musakkinat, mudirrat, muqawwi kabid and mufarrehat.

Dafe Humma lowers the body temperature by virtue of its innate property. Khaksi has an enormous effect to lower the raised body temperature. Khaksi (Sisymbrium irio), Karanjwah (Caesalpinia bonducella), Bada-aaward (Fagonia arabica), Kankana (Cinchona officinalis), Atees (Aconitum heterophyllum) are used for this purpose 5,8,9,10,11.

Muárriqat are drugs which induce sweating. Perspiration helps in lowering the body temperature by taking away latent heat from the body. Muárriqat also helps to get rid of the fever by removing the morbid matter from the body that is why the sweat of a patient of fever is foul smelling as it contains mawad-e-fasida (noxious matter). Pudeena (Mentha piperita), Badranjboya (Melissa officinalis/ Nepta cataria), Gul-e-Babuna (Matricaria chamomilla) are mostly used Unani medicines for this purpose ${ }^{9,11}$.

Musaffiyat wa Muáddilat-e-dam also lowers the body temperature by decreasing the ghilyaan and ufoonat of the blood. According to the concept of tibb-e-Unani there is ghilyan (excessive heat) in the blood in case of humma ufoonia. To decrease the ghilyan of the blood it is necessary to use some muáddilat-e-dam. These muáddilat-e-dam normalize the excessive heat of the blood by virtue of its mizaje barida (cold temperemant). Aalu Bukhara (Prunus domestica), unnab (Zizyphus vulgaris), gilo (Tinospora cardifoilia), tamar hindi (Tamaridus indica) are being used for this purpose $8,9,10,11$.

Musaffiyat not only detoxifies the mawad-e-faasida (noxious matter) produced by infection. This detoxification takes place either by making the morbid/ noxious matter removable from the body or by nullifying its toxicity. Musaffiyat also checks the infection and reduce the production of morbid/ noxious matter. Most of the musaffiyat being cold in temperament also acts as coolant of the blood. Therefore, musaffiyat act in various ways to control the raised body temperature and to restore healthy blood and healthy body. Chiraita (Swertia chirata), shahtara (Fumaria officinalis), gilo (Tinospora cordifoilia), chobchini (Smilax china), ushba (Smilax ornata) are being used for this purpose $8,9,10,11$.

Mubarridat by virtue of its mizaj (temperament) and cooling effect lowers the raised body temperature to normal. According to Ibn-e-Sina, luab isapghol, beehdana, aab khurfa, rub-us-soos are bil-quwa and bil-feál cold (by virtue of their strength and action), therefore these are the best musakkin/ mubarrid4. Kafoor (Cinnamomum camphora), tabasheer (Bambusa arundinacea), rehan (Ocimum sanctam), khurfa siyah (Portulaca oleracea), qinnab (Cannabis sativa), asapghol (Plantago ovata) are being used for this purpose $7,8,9,10,11$. 
Mudirrat are used to detoxify the blood by eliminating the toxins and noxious matter which are produced in humma-eufoonia. Fever being the hyper-metabolic state, produces waste material in excess to normal; therefore use of mudirrat helps to remove these wastes from the body rapidly. Parsiyaoshan (Adiantum capillus), tukhm tarbooz (Citrullus vulgaris), khurfa (Portulaca oleracea) and kutki (Picrorhiza kurroa) are being used for this purpose ${ }^{10,11}$.

Muqawwi Kabid medicines are also a part of prescription for hummiyat. One aspect of using muqawwi kabid drugs is that it protects the liver/ body from the mawad-e-fasida (morbid matter) produced during fever. Another aspect is to produce akhlat-e-saleha in a greater quantity and of best quality. Aftimoon (Cuscuta reflexa), kasaundi (Cassia occidentalis), kutki (Picrorhiza kurroa), baranjasif (Artemisia vulgaris), afsanteen (Artemisia absinthium), zarishk (Berberis vulgari), bathua (Chenopodium album) are being used for this purpose $8,9,10,11$.

Mufarrehat are used to boost the quwwat-e-manaát and it gives the feeling of well being to the patient. Rehan (Ocimum sanctam), badranjboya (Melissa officinalis/ Nepta cataria), sandal (Santalum album) are being used for this purpose.

\section{CONCLUSION}

After reviewing different dimensions of management of fever, it may be concluded that the approach is holistic management. It comprises ilaj bil ghiza, ilaj bit tadbeer and ilaj bil dawa. Ilaj bil ghiza including use of cold water is much elaborative and rational in order to protect and strengthen the tabiát to combat the ailing condition efficiently. Ilaj bit tadbeer to normalize the body temperature in a natural way and finally ilaj bil dawa with dafe humma, muárriqat, muáddilat-e-dam wa musffiyat, mubarridat, mudirrat and muqawwi kabid drugs. Use of all these drugs lowers the raised body temperature by different ways, i.e. by their cooling effect, detoxifying the body from morbid/ noxious matter and by providing strength to tabiát as discussed above in detail.

\section{REFERENCES}

1. Arzani, A., Tibb-e-Akbar (urdu translation by Mohammad Husain), Re-print by Idara Kitab-us-Shifa, New Delhi, (originally printed by Matba Munshi Naval Kishore Lucknow in 1903), 1903; pp 633, 648

2. Tabri, R.A.H., Firdaus-ul-Hikmat, Idara Kitab-us-Shifa, Koocha Chelan, Darya Ganj, New Delhi, 2010; pp 270, 273

3. Kabeeruddin, M., Tarjuma Sharah Asbab, Volume 3-4, Idara Kitab-us-Shifa, New Delhi, 2009; pp 416-438, 557

4. Sina, I., Al-Qanoon fit Tib (urdu translation by G.H. Kantoori), Re-print by Idara Kitab-us-Shifa, New Delhi, 2010; pp 11631164, 1167

5. Khan, M. A., Akseer Azam, Idara Kitab-us-Shifa, New Delhi, 2009; 854

6. Jurjani, I., Zakheera Kwarzam Shahi (urdu translation by Hadi Hasan Khan), Volume 5, Matba Nami Munshi Naval Kishore, Lucknow, 1878; pp 29-31, 38

7. Razi, Z.A.B., Kitab-ul-Mansoori, Urdu Translation, CCRUM, New Delhi, 1991; 397-418.

8. Ali, S.S., Unani Advia-e-Mufrada, $6^{\text {th }}$ Edition, Taraqqi Urdu Bureau, New Delhi,1993; pp 19, 28, 38, 45, 64, 69, 129, 142, 145, 169, 195, 201, 215, 243.

9. Hakeem, M.A., Bustan-ul-Mufradat, Idara Kitab-us-Shifa, Koocha Chelan, Darya Ganj, New Delhi, 2002; pp 71, 108, 110, 121, 141, 195, 230, 256, 371, 416, 417, 439, 489

10. Kabeeruddin, M., Makhzan-ul-Mufradat Al-Maroof Khawas-ulAdvia, Aijaz Publishing House, New Delhi, YNM; pp. 62, 72, 80, $90,91,109,120,233,263,267,313,379,398,403,430,450$

11. Kirtikar, K.R. and Basu, B.D., Indian Medicinal Plants, Vivek Vihar, Delhi, 1981; pp 77, 138, 156, 242, 842, 887, 1023, 1383, 1398, 1664, 1825, 2072, 2725. 